\title{
Earthquake Performance of free Standing four Legged Greenfield Towers
}

\author{
A. M. L. N. Gunathilaka, C. S. Lewangamage and M. T. R. Jayasinghe
}

\begin{abstract}
Telecommunication/broadcasting towers play a vital role in telecommunication and broadcasting sectors by facilitating wireless data and signal transmissions. The failure of a tower especially under a disaster situation such as earthquake is a major concern mainly in two ways. One is the failure of communication/broadcasting facilities which will become a major setback to carry out rescue and other essential operations during a disaster while failure of a tower will itself cause a considerable economic loss as well as damages to human life since these are tall giant structures in most of the cases.

Presently, a strong dialogue is going on amongst the professionals regarding the seismic condition of our country with the reported earth tremors in recent times. Hence, evaluating the structural performance of existing telecommunication/ broadcasting towers under seismic loads is utmost important since almost all existing towers have not been designed considering seismic forces due to traditional belief that Sri Lanka will not be subjected to earthquakes of appreciable magnitudes.

Considering the above situation, assessment of structural performance of existing towers (which were not initially designed considering earthquake loading) under possible earthquake loading with different analytical techniques was selected as main objective of this study. Accordingly, behaviour of existing four legged Greenfield towers under seismic loading using ANSI/TIA-222-G tower design code was studied and results, observations and conclusions based on this analysis are presented.
\end{abstract}

Key words: Telecommunication towers, seismic loading

\section{Introduction}

With the revolutionary development in telecommunication and broadcasting sectors of the country during last few decades, a large number of telecommunication / broadcasting towers are available in the country to facilitate wireless data and signal transmissions. Most of these towers have been constructed after early 1990's with the introduction of mobile telecommunication technology to Sri Lanka.

Almost all telecommunication/broadcasting towers in Sri Lanka are steel towers. But, different structural forms have been adopted as per the requirements. Since these are erected out of steel, they are relatively light weight structures and wind loads are critical loadings for the design. Seismic forces may also become critical due to tall nature of these structures, but those have not been considered for almost all tower designs since Sri Lanka was considered as a country generally free from earthquakes until recently.

However, now most of the structural designers and professionals are aware of the importance of considering seismic effects for their designs with earthquake that caused Tsunami in 2004 and recent earth tremors reported in the country. Further, various geo specialist, researchers and scientists have also highlighted the essentiality of implementing seismic design approach for important structures.

Structural engineers in the country started to incorporate seismic effects for their designs especially for high rise buildings and other major structures such as dams with this situation. However, seismic effects are not considered for local telecommunication tower designs yet.

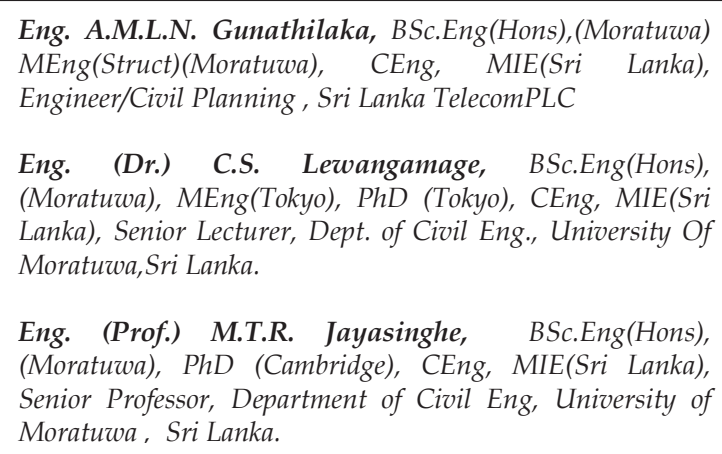


Hence, assessment of existing telecommunication/broadcasting structures under seismic loading has become an important issue since these towers play a vital role by facilitating essential communication needs during post disaster recovery operations after a possible earthquake. Further, a failure of tower will itself cause a considerable economic loss as well as possible loss of lives.

Accordingly, analysis of telecommunication towers under relevant seismic loads was selected as the scope of this study, since such a study considering local conditions will be important.

\section{Objectives}

The main objective of this research is assessing the performance of exiting towers (which were not initially designed considering earthquake loading) under possible earthquake loading and finding of cost effective strategies for retrofitting in case such action has to be effected.

Various types of telecommunication towers with different structural forms are available in the country and this study has been limited to analysis of four legged Greenfield self supporting lattice towers, which are the most common type of telecommunication towers in this country.

\section{Methodology}

Three towers having different tower heights of $30 \mathrm{~m}, 50 \mathrm{~m}$ and $80 \mathrm{~m}$ were selected for this analysis as most of the Green field telecommunication towers of Sri Lanka are within the height range from $30 \mathrm{~m}$ to $80 \mathrm{~m}$. Generally, these towers have been designed for wind speed of $50 \mathrm{~m} / \mathrm{s}(180 \mathrm{~km} / \mathrm{h})$, which is slightly above the recommended design wind speed for Zone 1 for normal structures [4].

ANSI/TIA-222-G-2005 [1] Structural Standard for Antenna Supporting Structures and Antennas, which is highly appreciated and very commonly used code of practice by both local and foreign tower designers, has been used for the structural analysis and design of towers under both wind and seismic loadings.

3D computer models for each tower was prepared using SAP2000 structural analysis software [16] and analysis of towers under both wind and earthquake loads was carried out using such models. Finally, the results of analyses under wind and earthquake loads were compared.

Designs of the towers were verified for design wind speed of $50 \mathrm{~m} / \mathrm{s}$ using computer analysis results as the first step. Towers were also analyzed for the wind speed of $33.5 \mathrm{~m} / \mathrm{s}$ (recommended design wind speed for Zone 3 Normal structures condition for Sri Lanka) [4], which is the lowest allowable design wind speed that can be used for structural design in Sri Lanka, for the purpose of comparison of results.

For analysis of towers under earthquake loading, equivalent static method and response spectrum analysis technique given in ANSI/TIA-222-G-2005 [1] were used. Appropriate seismic loads/ response spectrums for Sri Lanka have been selected. Seismic analyses were also carried out under very severe and severe seismic conditions for comparison purpose.

\section{Loading}

\subsection{Wind loads}

Calculation of wind loads on towers were carried out according to ANSI/TIA-222-G2005[1] for the design wind speed of $50 \mathrm{~m} / \mathrm{s}$ $(180 \mathrm{~km} / \mathrm{h})$, which is close to the recommended design wind speed for Zone 1 Normal structures condition. Wind loads were also calculated for the wind speed of $33.5 \mathrm{~m} / \mathrm{s}$ (recommended design wind speed for Zone 3 Normal structures condition for Sri Lanka) [4], which is the lowest allowable design wind speed that can be used for structural design in Sri Lanka, for the purpose of comparison of results.

\subsection{Seismic loads}

For the calculation of seismic loads on towers, four methods are given in the ANSI/TIA-222G -2005[1]. Those methods are;

\section{Equivalent lateral force, method 1}

2. Equivalent Modal analysis, method 2

3. Modal analysis, method 3

4. Time history analysis, method 4

The first two methods of the above are equivalent static methods and the other two are dynamic analysis procedures. The equivalent static methods and the modal 
analysis (response spectrum analysis) technique were used in this study.

\subsubsection{Equivalent Static Method}

Equivalent static methods are the simplest analytical technique that can be used for seismic analysis. Two methods are given in ANSI/TIA-222-G -2005[1] for equivalent static analysis. For the selection of appropriate equivalent static method for an analysis, criteria has been given in the code and accordingly for the $30 \mathrm{~m}$ tower, method 1 was selected, while method 2 was selected for $50 \mathrm{~m}$ and $80 \mathrm{~m}$ towers. (Whole procedure of calculations under method 1 and 2 are described in Appendix " $\mathrm{A}$ ".)

For the calculation of seismic shear, Maximum considered earthquake spectral response acceleration at short period $\left(\mathrm{S}_{\mathrm{S}}\right)$ and Maximum considered earthquake spectral response acceleration at 1.0 second $\left(S_{1}\right)$ are required. These are site specific acceleration coefficients and these values for countries other than USA have not been given in ANSI/TIA-222-G-2005 [1]. Further, recommended seismic acceleration parameters are not locally available, since code of practice for seismic design is not available in Sri Lanka yet.

Hence, these values had to be obtained from other foreign sources and previous local studies done in this regards. Hence, US Geological Survey (USGS) website (www.usgs.gov) [15] was referred as the initial step to find relevant values. The recommended $S_{s}$ and $S_{1}$ values for Sri Lanka in it are 0.03 and 0.01 respectively. Further, it has given an approximate method to calculate $S_{\mathrm{s}}$ and $S_{1}$ by multiplying Peak Ground Acceleration at a specific sites for a $10 \%$ probability of exceedance in 50 year by a factor of 5 and 2 respectively as per the recommendation of Global Seismic Hazard Programme (GSHAP).

The validity of $S_{s}$ and $S_{1}$ values given in USGS website is quite questionable since local researchers, who have done research in this area have some other thoughts. As per the research done by Peiris [13], design Peak Ground Acceleration at rock sites for a $10 \%$ probability of exceedance in 50 year or 475 year return period for Colombo is $0.026 \mathrm{~g}$. But, in very recent research done by Uduweriya et al [14] , a Peak Ground Acceleration of 0.1g is recommended for Colombo. Further in the study on Performance of Tall Buildings done by Jayasinghe et al [11], seismic acceleration in the range of $0.10 \mathrm{~g}$ to $0.15 \mathrm{~g}$ had been used, which is quite close to the recommendations of Uduweriya et al [14]. Therefore, it was decided to calculate $S_{\mathrm{s}}$ and $S_{1}$ using the approximate method given in USGS website[14] based on Peak Ground Acceleration of $0.1 \mathrm{~g}$. Accordingly, calculated $S_{\mathrm{s}}$ and $S_{1}$ were 0.5 and 0.2 respectively. These two values are quite close to the recommended values for south India and cities in Australia in USGS, where similar type of seismological condition exists when compared with Sri Lanka. This would correspond to moderate damage condition.

Since towers are generally constructed on sites with good soil conditions, site specific geotechnical condition is considered as Site Class " $\mathrm{C}$ ".

In order to compare the seismic performance of towers under higher earthquake magnitudes, two other set of site specific acceleration coefficients were also considered. Accordingly, site specific acceleration coefficients for Nepal as $S_{\mathrm{s}}=2.14$ and $S_{1}=0.86$ and for Pakistan as $S_{\mathrm{s}}=1.22$ and $S_{1}=0.49$ given in USGS website was selected. The conditions applicable to Nepal represent very severe seismic condition while those for Pakistan represent severe seismic condition.

For the calculation of fundamental natural frequency of a tower, a formula has been given in ANSI/TIA-222-G-2005 [1]. However, to obtain better accuracy, natural frequencies were obtained from the modal analysis performed using SAP 2000 model and calculated fundamental natural frequencies for $30 \mathrm{~m}, 50 \mathrm{~m}$ and $80 \mathrm{~m}$ towers are $2.56 \mathrm{~Hz}, 2.32$ $\mathrm{Hz}$ and $1.20 \mathrm{~Hz}$. The formula given in ANSI/TIA-222-G [1] gave values of $4.11 \mathrm{~Hz}$, $2.54 \mathrm{~Hz}$ and $1.41 \mathrm{~Hz}$ for $30 \mathrm{~m}, 50 \mathrm{~m}$ and $80 \mathrm{~m}$ towers respectively. Comparing fundamental natural frequencies obtained from SAP models and from formula given in code for respective towers, it is evident that frequencies obtained from formula are always higher and they would produce higher base shear values as well.

\subsubsection{Response Spectrum Analysis}

For the purpose of carrying out Response spectrum analysis of towers, clear guidelines are given in ANSI/TIA-222-G[1]. Accordingly, design response spectrums have to be developed for each case by considering local seismological parameters and structural 
characteristics of towers. Equations given to develop response spectrum are as follows;

$\mathrm{f}_{\mathrm{m}} \quad=$ Frequency of structure for the mode under consideration

$S_{\mathrm{am}}=$ Design spectral response acceleration at period $\mathrm{Tm}$ for the mode under investigation

$\mathrm{T}_{\mathrm{m}} \quad=1 / \mathrm{f}_{\mathrm{m}}$

for $\mathrm{T}_{\mathrm{m}}<4.0 \mathrm{sec}$

$\mathrm{S}_{\mathrm{am}}=\mathrm{S}_{\mathrm{DS}}\left(0.4+0.6 \mathrm{~T}_{\mathrm{m}} / \mathrm{T}_{0}\right)$ when $\mathrm{T}_{\mathrm{m}}<=\mathrm{T}_{0}$

$\mathrm{S}_{\mathrm{am}}=\mathrm{S}_{\mathrm{DS}}$ when $\mathrm{T}_{0}<\mathrm{T}_{\mathrm{m}}<\mathrm{T}_{\mathrm{s}}$

$\mathrm{S}_{\mathrm{am}}=\mathrm{S}_{\mathrm{D} 1} / \mathrm{Tm}$ when $\mathrm{T}_{\mathrm{m}}>=\mathrm{T}_{\mathrm{s}}$

For $\mathrm{T}_{\mathrm{m}}>4.0 \mathrm{sec}$

$\mathrm{S}_{\mathrm{am}}=4 \mathrm{~S}_{\mathrm{D} 1} / \mathrm{T}_{\mathrm{m}}^{2}$

Where;

$S_{D S}=$ Design spectral response acceleration at short periods

$\mathrm{S}_{\mathrm{D} 1}=$ Design spectral response acceleration at a period of 1 second

$\mathrm{T}_{0} \quad=0.2 \mathrm{~S}_{\mathrm{D} 1} / \mathrm{S}_{\mathrm{DS}}$

$\mathrm{T}_{\mathrm{S}}=\mathrm{S}_{\mathrm{D} 1} / \mathrm{S}_{\mathrm{DS}}$

As per the above formula response spectrum curves were developed.

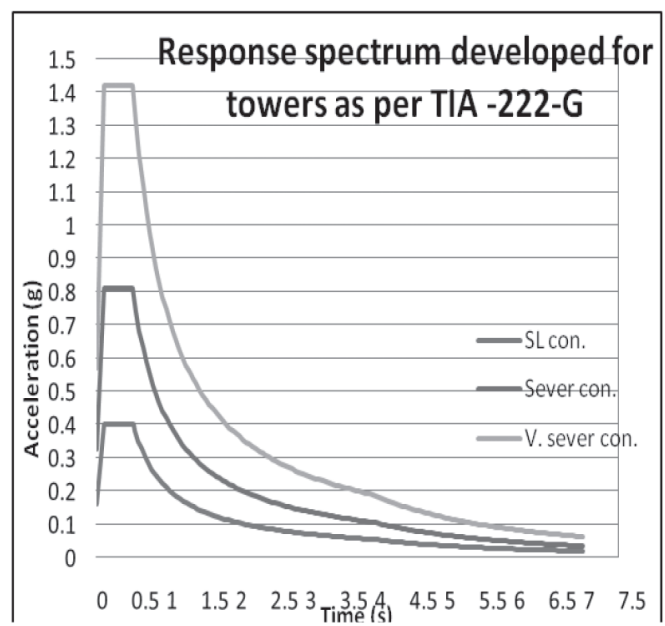

Figure 1 - Response spectrums developed for towers as ANSI/TIA-222-G

Same seismological parameters selected for Static equivalent analysis were used for development of Response spectrums too in respective cases.
As per the specification given in ANSI/TIA$222-G$ [1], more than $85 \%$ modal mass participation were ensured in all spectrum analysis cases by considering appropriate number of modes. Accordingly, 12 modes were considered for $30 \mathrm{~m}$ and $50 \mathrm{~m}$ tower cases, while it had to consider 30 modes for 80 $\mathrm{m}$ tower to satisfy above criteria. 5\% damping ratio was assumed in all cases as suggested in ANSI/TIA-222-G-2005[1].

\section{Three Dimensional Modeling}

As mentioned earlier, 3D finite element truss models were prepared for all three $(30 \mathrm{~m}, 50 \mathrm{~m}$ and $80 \mathrm{~m}$ ) towers. All structural members of these towers were defined as standard " $\mathrm{L}$ " angel members and Grade of steel of leg members were taken as S355 and all other members as S275 as in actual towers.

Each of the towers was subdivided to panels according to geometries of towers and wind and earthquake load under static equivalent analysis were separately calculated for each panel. The calculated wind and earthquake loads for each panel were assigned as nodal loads for respective tower models.

Response spectrum curves that were developed as per the guideline of ANSI/TIA222-G-2005 [1] were input into respective SAP models as user define curves. Auto generated self weights of the respective SAP models were considered as mass source for response spectrum and modal analysis.

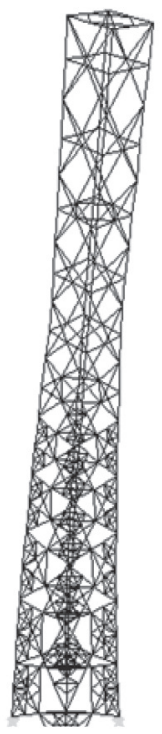

$30 \mathrm{~m}$ tower
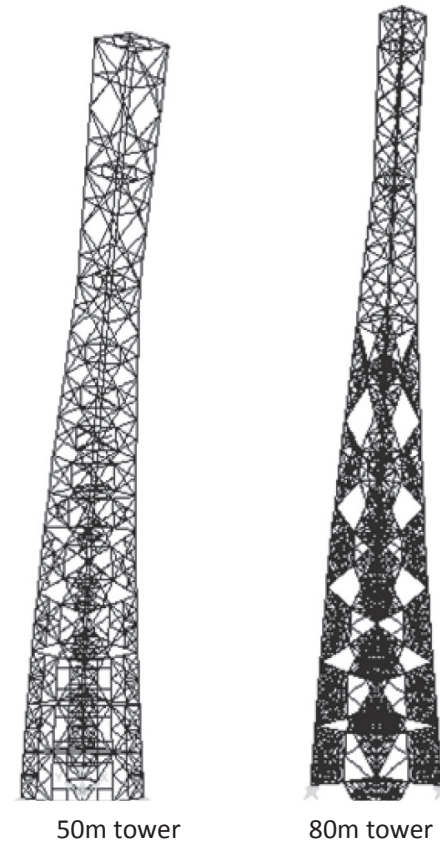

$80 \mathrm{~m}$ tower
Figure 2- 3D SAP models 
However, to compensate for mass of antennas and other ancillaries (such as ladders, feeder cables, platforms, etc) material density of member materials were modified by a factor individually calculated for each model based on ratio of pure weight of tower members and actual weight of tower including all ancillaries. A similar approach have been adopted by Amiri et al [7] for modeling of telecommunication towers under seismic loading in their research. Consideration of masses of all ancillaries is important since mass of such items could contribute significantly for seismic force generation of a tower under an earthquake as the weight of ancillaries including antennas takes considerable portion of overall self weight of a actual tower.

Maximum support reactions and stresses in leg members are developed when lateral loads are applied along a diagonal of the plan of a tower. Hence, both wind and seismic loads are applied along a diagonal direction. As per ANSI/TIA-222-G-2005[1] specifications, following load cases given in Table 1 were considered in this study.

\begin{tabular}{|c|c|c|}
\hline $\begin{array}{l}\text { Load } \\
\text { case }\end{array}$ & $\begin{array}{l}\text { Case } \\
\text { Name }\end{array}$ & Remarks \\
\hline 1 & $\begin{array}{l}\text { 1.2XDead } \\
+ \\
\text { 1.6XWind }\end{array}$ & Under $50 \mathrm{~m} / \mathrm{s}$ wind speed \\
\hline 2 & $\begin{array}{l}\text { 0.9XDead } \\
+ \\
\text { 1.6XWind }\end{array}$ & Under $50 \mathrm{~m} / \mathrm{s}$ wind speed \\
\hline 3 & $\begin{array}{l}\text { 1.2XDead } \\
+ \\
\text { 1.6XWind }\end{array}$ & Under $33.5 \mathrm{~m} / \mathrm{s}$ wind speed \\
\hline 4 & $\begin{array}{l}\text { 0.9XDead } \\
+ \\
\text { 1.6XWind } \\
\end{array}$ & Under $33.5 \mathrm{~m} / \mathrm{s}$ wind speed \\
\hline 5 & $\begin{array}{l}\text { 1.2XDead } \\
+ \\
\text { 1.0XEarth. }\end{array}$ & $\begin{array}{l}\text { Earthquake load under } \\
\text { Appropriate condition for SL }\end{array}$ \\
\hline 6 & $\begin{array}{l}\text { 0.9XDead } \\
+ \\
\text { 1.0XEarth. }\end{array}$ & $\begin{array}{l}\text { Earthquake load under } \\
\text { Appropriate condition for SL }\end{array}$ \\
\hline 7 & $\begin{array}{l}\text { 1.2XDead } \\
+ \\
\text { 1.0XEarth. }\end{array}$ & $\begin{array}{l}\text { Earthquake load under very } \\
\text { severe seismicity condition }\end{array}$ \\
\hline 8 & $\begin{array}{l}\text { 0.9XDead } \\
+ \\
\text { 1.0XEarth. }\end{array}$ & $\begin{array}{l}\text { Earthquake load under very } \\
\text { severe seismicity condition } \\
\text { Under very severe seismicity }\end{array}$ \\
\hline 9 & $\begin{array}{l}\text { 1.2XDead } \\
+ \\
\text { 1.0XEarth. }\end{array}$ & $\begin{array}{l}\text { Earthquake load under severe } \\
\text { seismicity condition }\end{array}$ \\
\hline 10 & $\begin{array}{l}\text { 0.9XDead } \\
+ \\
\text { 1.0XEarth. }\end{array}$ & $\begin{array}{l}\text { Earthquake load under severe } \\
\text { seismicity condition }\end{array}$ \\
\hline
\end{tabular}

Table 1 - Load combinations considered for analysis
Under the load cases 5 to 10 of Table 1, static Equivalent load case and load generated by Response spectrum analysis were considered as sub load cases (a) and (b) respectively in each case.

\section{Analysis Results \& discussion}

Supports reactions, maximum axial forces in leg members and maximum horizontal deflections of each tower for the load combinations described above were obtained from SAP 2000 analysis results of respective tower models.

Figure 3 shows the maximum downward reactions in towers under wind and earthquake loading. Further, figure 4 shows the same results without wind load cases to obtain better comparison between different seismic load cases. Figure 5 and 6 show the similar data with respect uplift reaction of towers while figure 7 shows similar data with respect to maximum horizontal reaction of towers.

As expected, maximum uplift reactions in each and every case are observed when dead load has a factor of safety of 0.9 , while maximum downward and horizontal reactions are observed when dead load has a factor of safety of 1.2 .

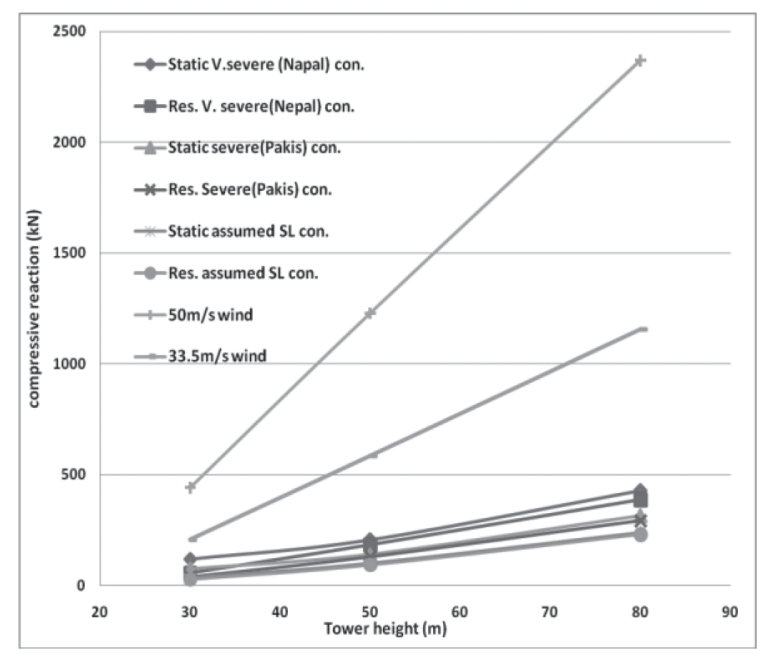

Figure 3 -Comp. reactions under wind \& seismic loads 


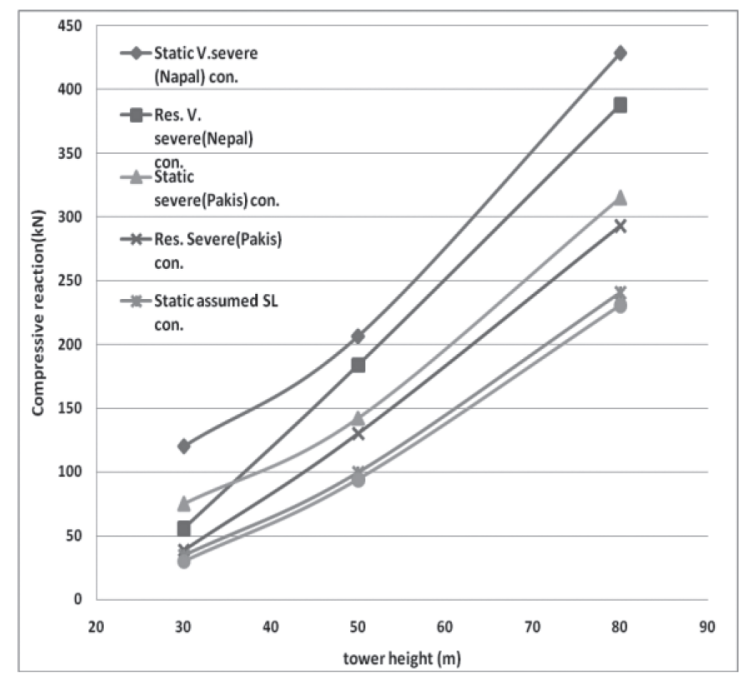

Figure 4 - Comp. reaction under seismic load cases

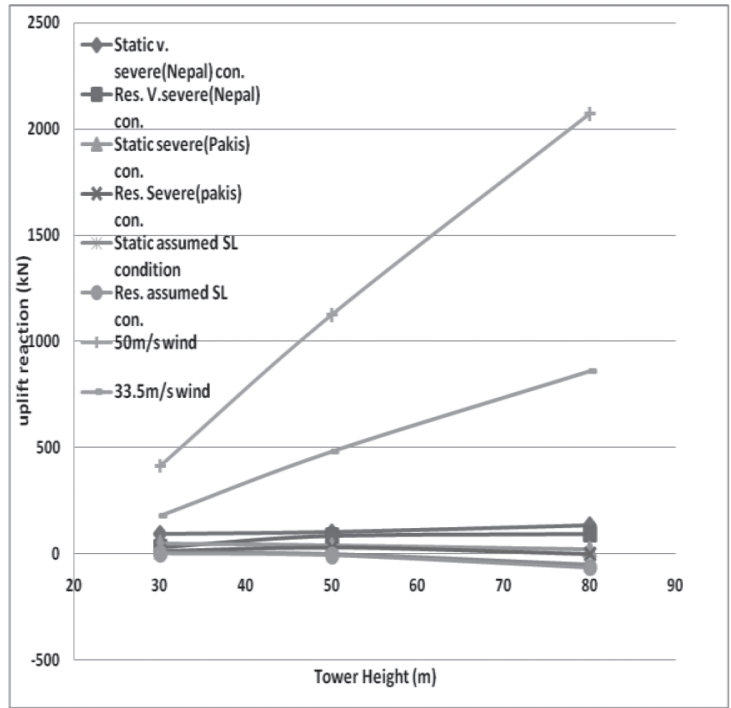

Figure 5 - uplift reactions under wind \& seismic loads

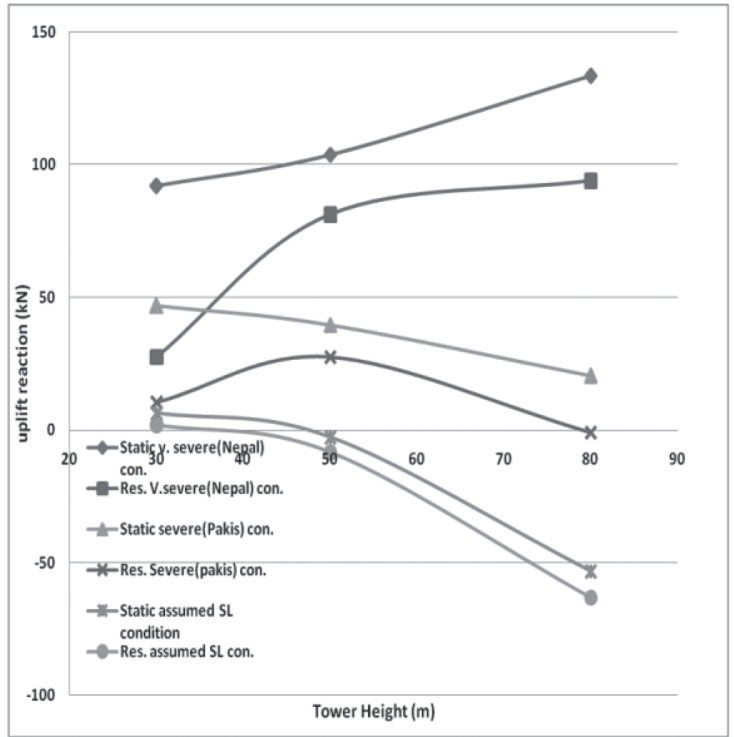

According to results as displayed in graphs, support reactions under assumed earthquake loading condition for Sri Lanka are very much less than the support reaction under design wind loading, even for design wind speed of $33.5 \mathrm{~m} / \mathrm{s}$. Further, the gap between support reactions values under wind loading and earthquake loading increases with the increase of tower heights. Another important observation is that there are no uplift reactions under assumed earthquake loading condition for Sri Lanka in $50 \mathrm{~m}$ and $80 \mathrm{~m}$ tower cases.

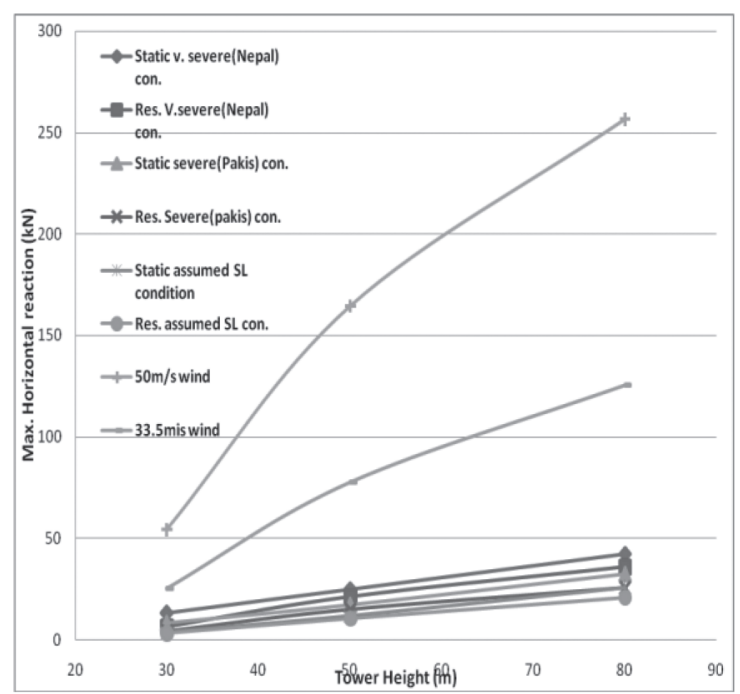

Figure 7- Horizontal reactions under seismic and wind load cases

It can be observed that support resections of $30 \mathrm{~m}$ tower under very severe seismic load condition analyzed using equivalent static load method are reaching close to the design support reactions if the tower had been designed considering design wind speed 33.5 $\mathrm{m} / \mathrm{s}$. But, in the results of response spectrum analysis, considerable gap can be observed between reaction under wind loading and very sever seismic loading. In the meantime, support reactions under both wind load conditions are far dominant in other two towers when comparing reactions under very severe seismicity. 


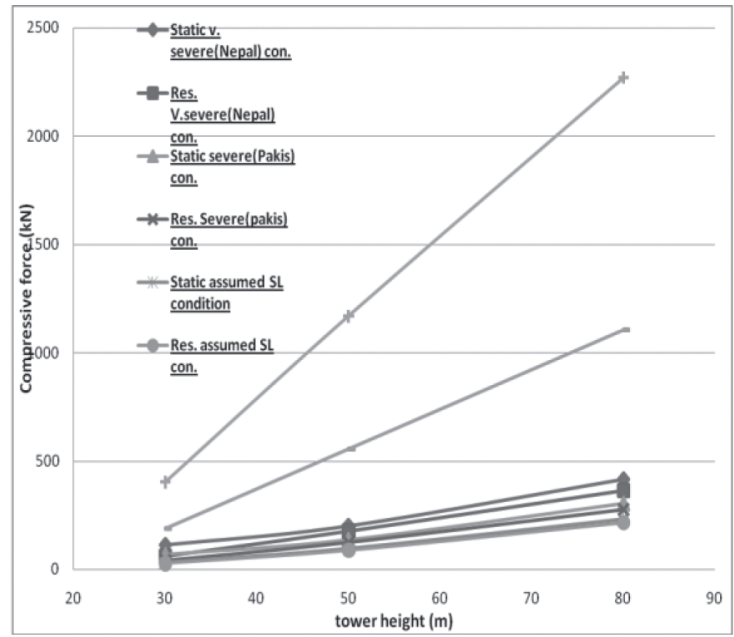

Figure 8 - Comp. forces in legs under wind \& seismic loads

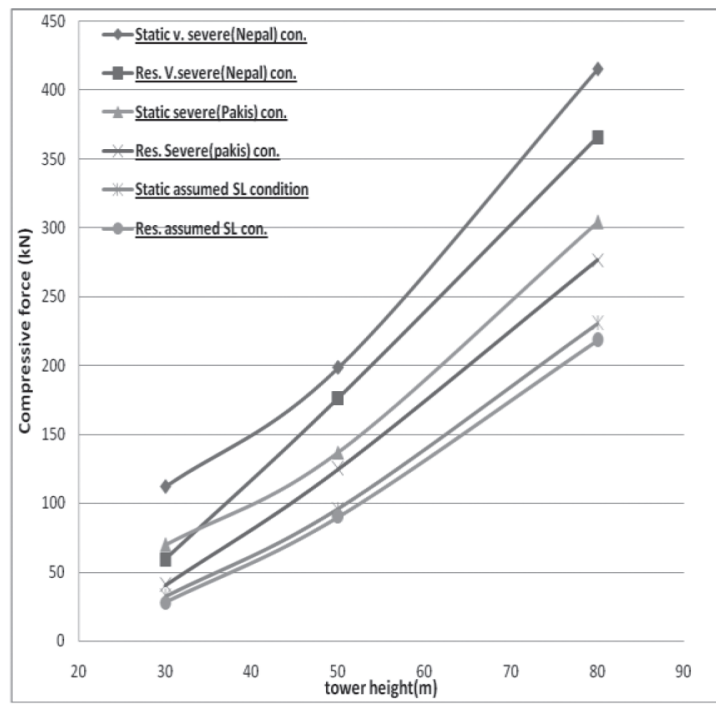

Figure 9 - Comp. forces in legs under seismic loads

Variation of axial compressive forces under different wind and earthquake conditions are shown in Figures 8 and 9. In Figure 9, forces under wind loading have not been displayed to obtain better comparison between earthquake loading combinations. Figures 10 and 11 are similar type of graphs, which display the variation of maximum tensile forces in leg members.

As it expected, the variation pattern of maximum compressive forces in leg members under different loading conditions (as shown in Figures $8 \& 9$ ) are quite similar to the variation pattern of compressive reactions. The same behaviour is observed when compared variation of tensile forces in leg members with variation of uplift reactions.

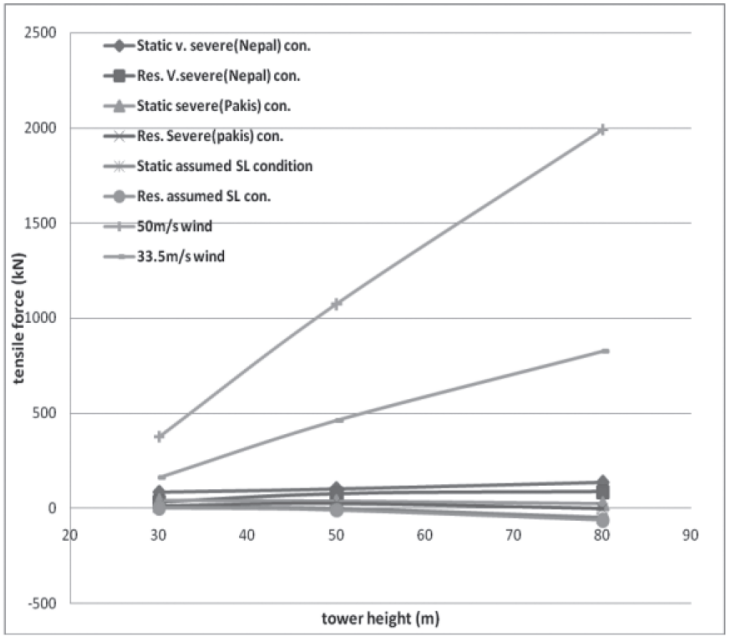

Figure 10 - Tensile forces in legs under wind and seismic load cases

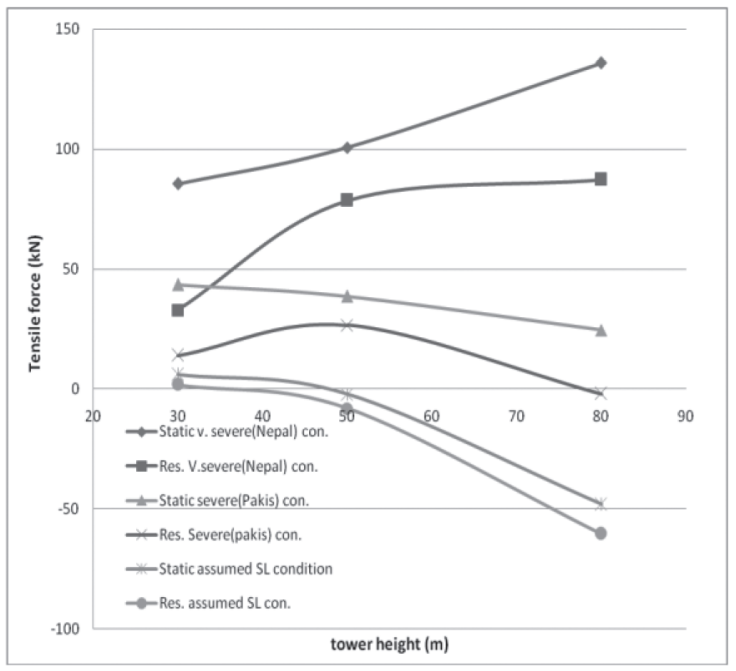

Figure 11 - Tensile forces in legs under seismic loads

Maximum deflections of towers under selected wind and seismic load combinations are shown in figure 12. Deflections under wind load combinations are far dominant compared with deflections under seismic loading in all considered towers. The gap between wind deflections and seismic deflections are increasing with the increase of tower height showing the same pattern that was observed regarding other structural actions as well.

Accordingly, when the overall results of this analysis are considered, it is quite evident that stresses and deformations in all three selected towers under all seismic loading combinations are far below when compared with same under wind load combinations, except in $30 \mathrm{~m}$ tower. Even in $30 \mathrm{~m}$ tower, wind load combinations are still dominant compared with seismic load combinations. 


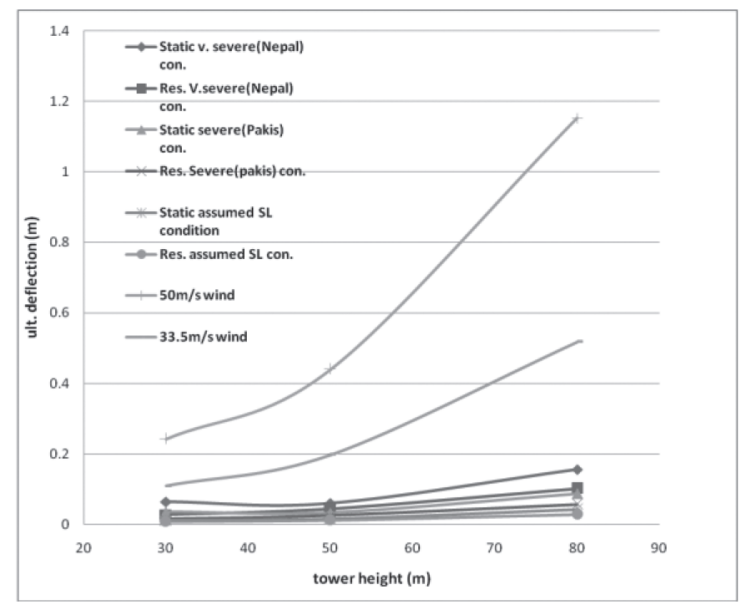

Figure 12 - Variation of maximum deflections under seismic \& wind loadings

Similar type of results have been reported from previous researches done in other countries as well. A research carried out by Amiri \& Boostan[7] on telecommunication towers in Iran, showed that design forces/reactions under wind loads are always dominant compared to earthquake loading and difference between magnitude of forces/reaction under wind load and seismic loading are increasing when height of the tower is increased. Also, ANSI/TIA-222-G2005[1] in itself has specified that analysis under earthquake loading for normal towers are not required if $S_{s}$ is less than or equal to 1.00. This has also been proved by this analysis.

The result of this study can also be used to compare the performance of equivalent static method and response spectrum method given in ANSI/TIA-222-G-2005[1] for seismic analysis of towers. According to results, it is observed that all structural actions developed under static equivalent analysis are higher than the values of same under response spectrum analysis in all three towers in all respective seismological conditions as well. The closest gap between structural actions values under static equivalent method and response spectrum method was seen in $50 \mathrm{~m}$ tower while widest gap between above values were observed in $80 \mathrm{~m}$ tower. Further, it is evident that gap between analytical result values under above two analytical techniques are closing up under lower seismicity conditions in all towers. (Under seismicity considered for Sri Lanka in this analysis, resultant curves of static equivalent analysis and response spectrum analysis are almost touching each other with respect to all structural actions). Therefore, it can presume that static equivalent analysis given in ANSI/TIA-222-G-2005[1] always produces conservative results in seismic analysis. However, it may be over conservative in certain cases as observed here.

In the meantime, it is important to consider sufficient number of vibration modes during response spectrum analysis to satisfy minimum $85 \%$ modal mass participation specified in the code. If modal mass participation is less due to non consideration of sufficient numbers of modes, erroneous results can be produced by the analysis. Especially for taller towers, it may have to consider large number of modes to satisfy above condition. example, in the $80 \mathrm{~m}$ tower case of this analysis, it had to consider 30 modes to satisfy the mass participation criteria.

The better performance of telecommunication towers under seismic loads that is identified in this analysis has also been practically observed under actual earthquakes. According to the field report prepared on structural and geotechnical damages sustained during the 26 January 2001 M 7.9 Bhuj Earthquake in Gujarat by Department of Civil Engineering, Indian Institute of Technology, Kanpur [12] (Bhuj earthquake is the most damaging earthquake reported in last few decades in India and over 18600 people were reported to be dead and reported economic loss is close to US\$ 5 billion), the telecommunication tower had performed very well and no significant damages had been observed, while other types of structures were experiencing major damages or collapsing. Also, in the research done by Moghtaderi-Zadeh on performance of life line systems in Bam Earthquake of 26 December 2003 in Iran[10], the good structural performance of telecommunication towers have been highlighted. Bam earthquake is an earthquake having magnitude of 6.5 in Richter scale and has caused more than 26000 deaths and major damages to most of the structures in the area.

\section{Conclusion}

As per the objective of this study, selected existing four leg green field lattice towers were extensively analyzed using different analytical techniques given in ANSI/TIA-222-G-2005 [1] to assess the structural performance of those towers under seismic loading and compared with wind load analysis. Accordingly, some 
interesting findings were seen as described below;

- Structural actions (member forces, support reactions deflections, etc) developed in all selected towers under most probable type of seismic loads relevant to Sri Lanka are very low compared with same under design wind loads. Hence, it can be expected that existing towers in this height range will survive without any problem under a minor to moderate earthquake, which is the most probable type of earthquake that can be expected to a country like Sri Lanka. Further, even under a major earthquake, structural actions in towers will not be greater than structural actions under design wind loads in all selected towers. Hence, it cannot expect a major problem in towers in this height range even under major earthquake.

- The equivalent static method given ANSI/TIA-222-G-2005[1] for seismic analysis will always give conservative results when compared with results of relevant response spectrum analysis. However, usage of equivalent static method may give over conservative results in certain case as observed in this analysis.

- According to results, it is not essential to carry out separate structural check for self supporting four leg Greenfield towers in Sri Lanka considering probable seismic loads, if such towers have been properly analyzed and designed as per relevant design wind speeds recommended for Sri Lanka.

- Further studies of seismic performance of telecommunication/broadcasting towers is essential since behaviour of towers having other structural forms such as Guy mast, monopoles, roof top towers, etc may show different behaviour under seismic load conditions.

\section{References}

1. ANSI/TIA-222-G 2005, Structural Standard for Antenna Supporting Structures and Antennas, Telecommunications Industry Association ,USA

2. Australian Standard AS 3995, Design of Steel Lattice Towers and Masts, Australia Standards Association, Sydney, Australia, 1994
3. CP3 : Chapter V: Part 2 : September : 1972, Code of Basic Data for the design of buildings Chapter V. Loading- part 2 wind load, British Standard Institution, United Kingdom.

4. Design of buildings for high winds - Sri Lanka Ministry of Local Government, Housing and Construction, Sri Lanka, 1980.

5. Khedr, M., A., H., "Seismic analysis of lattice towers", PhD thesis- McGill University , Montreal, Canada, 1998.

6. Gunathilaka, A., M., L., N., Lewangamage, C., S., Jayasinghe, M., T., R., "Analysis and Design of telecommunication towers for earthquake loading for sustainability", 2nd International Conference for Sustainable Built Environment, Kandy, 2012.

7. Ghodrati Amiri, G., Boostan, A., "Dynamic Response of Antenna Supporting Structures", $4^{\text {th }}$ Structural Specialty Conference of the Canadian Society of Civil Engineers, Canada, 2002.

8. Ghodrati Amiri, G., Barkhordari, M., A., Massah, S., R., "Seismic Behaviour of 4 - Legged Self-Supporting Telecommunication Structures", 13 th World Conference on Earthquake Engineering, Vancouver, Canada, 2004.

9. Ghodrati Amiri, G., Barkhordari, M., A., Massah, S., R., Vafaei, M., R. , “Earthquake Amplification factors for self supporting 4legged telecommunication towers, World Applied Science Journal 2(6): 635-643, 2007

10. Masoud Moghtaderi-Zadeh, Farrokh Nadim, and Mohammad Javad Bolourchi "Performance of Lifeline Systems in Bam Earthquake of 26 December 2003", Journal of Seismology and Earthquake Engineering-JSEE, Iran, 2004.

11. Jayasinghe, M., T., R., Hettiarachchi, D., S., Gunawardena, D., S., R., T., N., “ Performance of Tall Buildings with and without Transfer Plate under Earthquake loading" Engineer, Journal of Institution of Engineers, Sri Lanka, Volume XXXXV, No.02, pp13-22, 2012

12. A field report on structural and geotechnical damages sustained during the 26 January 2001 M7.9 Bhuj Earthquake in Western India, Department of Civil Engineering, Indian Institute of Technology Kanpur, India, 2001.

13. Peiris, L., M., N., "Seismic Hazard Assessment of Sri Lanka and Seismic Risk in Colombo", Risk Management Solutions, London, UK, 2008.

14. Uduweriya, S., B., Wijesundara, K., K., Dissanayake, P., B., R., " Seismic Risk in Colombo- Probabilistic Approach " SAITM Research symposium on Engineering Advancement (SAITM-RSEA2013) , 2013. 
15. http://www.usgs.gov, visited on $12^{\text {th }}$ Dec. 2012

16. Computers \& Structures, Inc. (1995) SAP2000 User's Manual, Berkeley, California.

\section{Appendix A}

\section{Calculation of equivalent static load for $30 \mathrm{~m}$} tower

The following equation is given in ANSI/TIA222-G [1] to calculate total seismic shear $V_{s}$ under method 1 and it was used for the calculation of earthquake loading of $30 \mathrm{~m}$ tower.

$\mathrm{V}_{\mathrm{s}}=\underline{\underline{\mathrm{S}}} \underline{\mathrm{WS}}$

Alternatively , for ground supported structures, $V_{s}$ need not be greater than

$\mathrm{V}_{\mathrm{s}}=\underline{\mathrm{f}}_{1} \underline{\mathrm{S}_{\mathrm{D}}} \underline{\mathrm{W}} \underline{\mathrm{W}}$

When the alternative equation for $V_{S}$ is used, $\mathrm{V}_{\mathrm{s}}$ shall not be less than $0.044 S_{\mathrm{DS}} \mathrm{WI}$ and for sites where $S_{1}$ equals or exceeds $0.75, V_{s}$ using the alternative equation shall not be less than

$\mathrm{V}_{\mathrm{s}}=\underline{0.5 S_{1} \mathrm{~W} \mathrm{I}}$ $\mathrm{R}$

$\mathrm{S}_{\mathrm{DS}}=2 / 3 \mathrm{~S}_{\mathrm{S}}$

$S_{D 1}=2 / 3 S_{1}$

Where;

$S_{D S}-$ Design spectral response acceleration at short period

$S_{D 1}$ Design spectral response acceleration at period of 1.0 second

$S_{1}$ - Maximum considered earthquake spectral response acceleration at 1.0 second

$S_{\mathrm{s}}$ - Maximum considered earthquake spectral response acceleration at short period

$\mathrm{f}_{1}$ - Fundamental frequency of the structure

W- Total weight of structure including appurtenances

I - Importance factor

$\mathrm{R}$ - Response modification coefficient equal to 3.0 for lattice self supporting structures

$\mathrm{V}_{\mathrm{s}^{-}}$Total seismic shear
The vertical distribution of seismic force was done according to following formula given in ANSI/TIA-222-G-2005[1].

$$
\begin{aligned}
& \mathrm{F}_{\mathrm{sz}}=\frac{\mathrm{W}_{\mathrm{z}} \mathrm{h}_{\mathrm{z}} \mathrm{ke}}{\mathrm{n}} \\
& \sum_{i=1} W_{i} h_{i}^{k e}
\end{aligned}
$$

Where;

$\mathrm{F}_{\mathrm{sz}}=$ Lateral seismic force at level $\mathrm{Z}$

$\mathrm{W}_{\mathrm{z}}=$ Portion of total gravity load assigned to level under consideration

$\mathrm{W}_{\mathrm{i}}=$ Portion of total gravity load assigned to level i

$\mathrm{h}_{\mathrm{z}}=$ Height from the base of the structure to level under consideration

$h_{i}=$ Height from the base of the structure to level i

$\mathrm{k}_{\mathrm{e}}=$ seismic force distribution exponent (taken as 2.0 is it can set as 2.0 for any structure)

\section{Calculation of equivalent static load for $50 \mathrm{~m}$ and $80 \mathrm{~m}$ towers}

The formula given under equivalent modal analysis procedure (method 2) is as follows;

$\mathrm{F}_{\mathrm{sz}}=\frac{\mathrm{S}_{\mathrm{az}} \mathrm{W}_{\mathrm{z}} \mathrm{I}}{\mathrm{R}}$

Where;

$\mathrm{F}_{\mathrm{sz}}=$ Lateral seismic force at level $\mathrm{z}$ under consideration

$\mathrm{S}_{\mathrm{az}}=$ Acceleration coefficient at height $\mathrm{z}$

$=a\left(S_{A}\right)^{2}+b\left(S_{D S}\right)^{2}$

$\overline{\left\{\left(S_{\mathrm{A}}\right)^{2}+\mathrm{c}\left(\mathrm{S}_{\mathrm{DS}}\right)^{2}\right\}^{1 / 2}}$

$a, b, c=$ Acceleration coefficients

$S_{A}=S_{D 1} f_{1}$ when $f_{1}<=S_{D S} / S_{D 1}$, otherwise $S_{\mathrm{A}}=\mathrm{S}_{\mathrm{DS}}$

$\mathrm{f}_{1}=$ fundamental frequency of structure

$\mathrm{S}_{\mathrm{DS}}=$ Design spectral response acceleration at short period

$\mathrm{S}_{\mathrm{D} 1}=$ Design spectral response acceleration at period of 1.0 second 
$\mathrm{W}_{\mathrm{z}}=$ Portion of total gravity load assigned to level under consideration

I = Importance factor

$\mathrm{R}$ = Response modification coefficient equal to 3.0 for lattice self supporting structures 
